\title{
Exploratory Research on Novel Coal Liquefaction Concept
}

\author{
Quarterly Report \\ April 1 - June 30, 1997
}

\author{
By \\ R. A. Winsachel \\ S. D. Brandes
}

Work Performed Under Contract No.: DE-AC22-95PC95050

\author{
For \\ U.S. Department of Energy \\ Office of Fossil Energy \\ Federal Energy Technology Center \\ P.O. Box 880 \\ Morgantown, West Virginia 26507-0880
}

By
CONSOL, Inc.

Research \& Development

4000 Brownsville Road

Library, Pennsylvania 15129 


\section{Disclaimer}

This report was prepared as an account of work sponsored by an agency of the United States Government. Neither the United States Government nor any agency thereof, nor any of their employees, makes any warranty, express or implied, or assumes any legal liability or responsibility for the accuracy, completeness, or usefulness of any information, apparatus, product, or process disclosed, or represents that its use would not infringe privately owned rights. Reference herein to any specific commercial product, process, or service by trade

name, trademark, manufacturer, or otherwise does not necessarily constitute or imply its endorsement, recommendation, or favoring by the United States Government or any agency thereof. The views and opinions of authors expressed herein do not necessarily state or reflect those of the United States Government or any agency thereof. 


\section{CONTRACT TITLE AND NUMBER:}

Exploratory Research on Novel Coal Liquefaction Concept

DOE Contract No. DE-AC22-95PC95050 -38

\section{CONTRACTOR NAME:}

CONSOL Inc.

Research \& Development

4000 Brownsville Road

Library, PA 15129

CONTRACT INITIATION DATE: May 24, 1995

ANTICIPATED COMPLETION DATE: May 23, 1998

GOVERNMENT AWARD: $\$ 1,314,477$ Total, $\$ 1,292,800$ Obligated

PRINCIPAL INVESTIGATORS: R. A. Winschel, S. D. Brandes

\section{SUBCONTRACTORS/PRINCIPAL INVESTIGATORS:}

- University of Kentucky Center for Applied Energy Research - F. J. Derbyshire, G. M. Kimber, R. K. Anderson, A. Vego, T. Rantell, D. Jacques

- LDP Associates - M. Peluso

CONTRACTING OFFICER'S REPRESENTATIVE: M. A. Nowak

REPORTING PERIOD: April 1 through June 30, 1997

CONTRACT OBJECTIVES: No Change

\section{SUMMARY OF TECHNICAL PROGRESS - OVERALL}

Task 3 experimental tests were concluded this quarter. Second-stage testing of first-stage distilled filtrates and of a Wilsonville resid from Run 263 were completed. The first-stage filtrates were found to have higher reactivity than the Wilsonville material.

Task 4 experimental testing was initiated. First-stage microautoclave tests were made at reduced catalyst loading and reduced solvent to coal ratio without negatively affecting coal conversion. Lower severity second-stage catalytic upgrading tests were begun. The single-pass resid conversion obtained in the first completed second-stage test was high (67-69\%). 
The engineering evaluation of the first-stage tests made under Task 3 was completed. Evaluation of second-stage Task 3 tests was started. Comparison of a second-stage test made with Wilsonville Run 263J ashy resid and those made with first-stage distilled filtered products was begun.

\section{SUMMARY OF TECHNICAL PROGRESS BY TASK}

\section{Task 3 - Flow Sheet Development}

\section{First-Stage Tests, Filtration and Distillation of First-Stage Products}

Task 3 tests completed last quarter included four successful Run 23-LA series tests (through Run 23d-LA). ${ }^{1}$ Distillation of the filtered products of these tests was completed this quarter to prepare feedstocks for second-stage testing (Table 1). Distillation of the composited filtrates of first-stage Runs 23-LA, 23a-LA and 23c-LA (produced last quarter) was carried out under vacuum with an atmospheric equivalent cut point temperature of $454^{\circ} \mathrm{C}\left(850^{\circ} \mathrm{F}\right)$, yielding $25.3 \%$ residue and $74.7 \%$ distillate. The residue had a softening point of $290^{\circ} \mathrm{C}$. This high softening point could be indicative of partially coked material. The next filtrate distillation (Run 23d-LA) was carried out at less severe conditions, at an atmospheric equivalent temperature of $416{ }^{\circ} \mathrm{C}$ $\left(780{ }^{\circ} \mathrm{F}\right)$. The products collected were in the proportions $29.5 \mathrm{wt} \%$ residue and $70.5 \mathrm{wt} \%$ distillate. The residue had a softening point of $165^{\circ} \mathrm{C}$. Analysis by simulated distillation of the residue gave $24.9 \mathrm{wt} \%$ boiling $<566{ }^{\circ} \mathrm{C}$, as opposed to $6 \mathrm{wt} \%$ boiling $<566{ }^{\circ} \mathrm{C}$ that was found in the residue of the composited filtrate.

Three one-liter autoclave tests were made this quarter (Runs 23f-LA, 23g-LA, and 23h-LA). All tests were made at the same conditions as Run $23-\mathrm{LA}\left(375^{\circ} \mathrm{C}, 60 \mathrm{~min}, 222 \mathrm{mmole} \mathrm{KOH} / \mathrm{kg}\right.$ dry coal, $\mathrm{HI}$ "E", solvent/dry coal $=1.9$ ) to produce sufficient feedstock for second-stage catalytic upgrading tests and to provide information on repeatability of one-liter test data. The integrated filter unit was used for all tests; however, filtration was not successful for Run 23g-LA (see below).

Mass and elemental balances were obtained on most of the Run 23-LA series tests. The material balances achieved for three of the tests (Runs 23f-LA, 23g-LA and 23h-LA) were $110.0 \%$, $104.1 \%$ and $98.4 \%$ respectively. The poor balances in Runs 23f-LA and 23g-LA are attributed to inaccuracies in the measured gas yields, which were $146 \mathrm{~g}, 133 \mathrm{~g}$, and $114 \mathrm{~g}$ for Runs 23f-LA, $23 g$-LA, and 23h-LA, respectively. 
Run 23f-LA was filtered in situ and yielded $165.08 \mathrm{~g}$ of filtrate (containing $0.3 \%$ quinoline insolubles (QI) and 3.5\% tetrahydrofuran insolubles (THFI)) and $20.39 \mathrm{~g}$ of filter cake (40.4\% QI and $44.9 \% \mathrm{THFI}$ ) (Table 2). As in the distillation of Run 23d-LA (performed at $416^{\circ} \mathrm{C}$ ), in order to provide a larger quantity of feed for second-stage tests and to reduce the possibility of cracking the first-stage product, a lower distillation cut point was chosen than $454{ }^{\circ} \mathrm{C}$ (the temperature used in Run 23-LA series tests through Run 23c-LA). The filtrate was distilled under vacuum to an atmospheric equivalent temperature of $426^{\circ} \mathrm{C}$. The products collected were in the proportions $27.9 \%$ residue and $72.1 \%$ distillate. The residue had the same softening point $\left(165^{\circ} \mathrm{C}\right)$ and a similar amount (19.9\%) of $<566{ }^{\circ} \mathrm{C}$ distillate (19.9\% vs $\left.24.9 \%\right)$ as the Run $23 \mathrm{~d}$-LA distillation residue.

Run 23g-LA was not successfully filtered in situ. Material lodged in the valve between the autoclave and the filter apparatus and prevented transfer of material to the filter. The product was sampled for elemental analyses and the remainder was filtered in the $200 \mathrm{~mL}$ filter apparatus off line (Table 2). Yield of filtrate was $143.37 \mathrm{~g}(0.2 \% \mathrm{QI}, 2.0 \% \mathrm{THFI})$. The filter cake yield was $15.61 \mathrm{~g}(40.8 \% \mathrm{QI}, 42.1 \% \mathrm{THFI})$. Correcting these results for the product removed for analyses, the yields are $165.13 \mathrm{~g}$ of filtrate and $17.98 \mathrm{~g}$ of filter cake; overall material balance for the run was $104 \%$. The filtration rate was calculated to be $225 \mathrm{~kg} / \mathrm{m}^{2} / \mathrm{h}$ with a cake resistivity of $34 \times 10^{10} \mathrm{~m} / \mathrm{kg}$. These data compare well with the $208 \mathrm{~kg} / \mathrm{m}^{2} / \mathrm{h}$ and $33 \times 10^{10} \mathrm{~m} / \mathrm{kg}$ achieved in Run 23-LA. The filtrate was distilled under vacuum to an atmospheric equivalent temperature of $440{ }^{\circ} \mathrm{C}$. The resulting products were in the proportions $25.5 \%$ residue and $74.5 \%$ distillate. The residue had a softening point of $255^{\circ} \mathrm{C}$. Analysis by simulated distillation of the residue gave $12.3 \%$ of the material boiling $<566^{\circ} \mathrm{C}$.

Run 23h-LA was filtered in situ and yielded $165.15 \mathrm{~g}$ of filtrate and $19.64 \mathrm{~g}$ of filter cake. Overall material balance was $98.4 \%$. The products are being held in reserve for Task 4 tests.

Product work-up for all one-liter autoclave tests includes gas chromatography of gaseous products. Hydrogen content previously was determined by difference. A direct hydrogen gas analysis is now being used.

Samples of light distillate oil obtained from the post-run flash of products from the one-liter autoclave were analyzed by simulated distillation to provide information for the engineering and economic evaluation. The data are given in Table 12. 


\section{Second-Stage Catalytic Upgrading}

The upgrading properties of the Run 23-LA series first-stage product were compared with those of a conventional two-stage liquefaction resid this quarter. Three microautoclave tests were made with Run 23d-LA distilled filtrate, (Runs 23d-1, 50 MA, 23d-2, 50 MA, and 23d-3, 50 MA (Table 3)) all at the same conditions $\left(440{ }^{\circ} \mathrm{C}, 60 \mathrm{~min}, 1 \% \mathrm{Mo}\right)$. Average $566^{\circ} \mathrm{C}^{+}$resid conversion for the three microautoclave tests was ca. $45 \mathrm{wt} \%$. This is $10-17 \mathrm{wt} \%$ higher than resid conversions obtained in microautoclave tests with Wilsonville Run $258 \mathrm{~A}$ deashed resid. ${ }^{2}$

Gas yield in Run 23aoc-1, 300 CSTR, (made last quarter ${ }^{1}$ ) was unusually high (17 wt \% MAF feed). A microautoclave test was made with Run $23 \mathrm{~d}$-LA distilled filtrate at $450{ }^{\circ} \mathrm{C}, 60 \mathrm{~min}$, and $1 \%$ Mo to examine the possibility that temperatures in the $300 \mathrm{~mL}$ CSTR had been monitored inaccurately and the run temperature was higher than $440{ }^{\circ} \mathrm{C}$. Resid conversion in this microautoclave test (Run 23d-4, 50 MA) was 62 wt \% (ca. 17 wt \% higher than the average of Runs 23d-1, -2, -3, 50 MA). Gas yield also was higher than in the lower temperature tests, but only by ca. 4 wt \% (to $7.7 \mathrm{wt} \%$ MAF feed). Calculations made using the ideal gas law and conditions in the reactor and those made using the collected volume of product gas were compared to evaluate if the gas yield determined for the $300 \mathrm{~mL}$ test was inaccurately calculated. Calculations made both ways were within one standard deviation and can not explain the high gas make in Run 23aoc-1, 300 CSTR. It is possible that the microautoclave tests may accurately represent trends, but not the magnitude of differences seen in the $300 \mathrm{~mL}$ reactor. Reaction severity will be further examined in the $300 \mathrm{~mL}$ CSTR in Task 4.

Two second-stage hydrotreating tests were completed in the $300 \mathrm{~mL}$ CSTR (Tables 4 and 5). Run 23dfg-1, 300 CSTR, was the second test made with first-stage products of the Run 23-LA series. The feed for this run contained a higher distillate content (ca. $20 \mathrm{wt} \%$ ) than the first test, Run 23oac-1, 300 CSTR (ca. 6 wt \%, see above), but in all other respects was a duplicate of the first run (Table 6). However, resid conversion for Run 23dfg-1, $300 \mathrm{~mL}$ CSTR was $65 \mathrm{wt} \%, 8 \%$ (abs.) higher than that which was obtained for Run 23oac-1, $300 \mathrm{~mL}$ CSTR. The hydrogen uptake and the hydrogen-to-carbon ratio of the $566{ }^{\circ} \mathrm{C}^{+}$fraction also were higher. Each of these results suggest that there may have been more hydro conversion activity in this run than in the previous one. This may, in part be related to less severe distillation of the feedstock.

A baseline test was made with products of the Wilsonville pilot plant to compare with the firststage products of the Run 23-LA series. Run 263J-1, 300 CSTR, was made with the distillation resid of interstage products from Wilsonville Run 263J. This resid contains undissolved coal, 
fresh resid, and recycled process solvent. Simdist analysis of the feed found it to contain $28.7 \%$ $566{ }^{\circ} \mathrm{C}^{-}$, with an IBP of about $425^{\circ} \mathrm{C}$. Resid conversion was $44 \%$, ca. 20 wt \% less than that obtained with the first-stage filtrates from Run 23-LA series tests. Light gas yield was over 18 wt \% (MAF feed basis), comparable to that obtained with the first-stage filtrates. THF extraction of Run 263J-1, 300 CSTR, feed gave $21.9 \mathrm{wt} \%$ IOM. The dry reactor-scrape product contained $64.9 \%$ IOM. This constitutes an increase in mass of IOM of 2.25:1. This result and the high gas yields may indicate that regressive polymerization reactions may have occurred and that the reaction conditions may have been too severe. This will be confirmed in work under Task 4 .

In order to assess the quality of the material remaining in the $300 \mathrm{~mL}$ reactor at the end of the run, the reactor products recovered without THF ("dry reactor scrape") from four of the $300 \mathrm{~mL}$ CSTR tests (DARo-1, 300 CSTR, 23oac-1, 300 CSTR, 23dfg-1, 300 CSTR, and 263J-1, 300 CSTR) were distilled to a $566{ }^{\circ} \mathrm{C}$ cut point. The distillate and resid samples were submitted for proximate and ultimate analysis The results are summarized in Tables $7-10$. The $\mathrm{H} / \mathrm{C}$ ratio of the $566{ }^{\circ} \mathrm{C}^{+}$ fraction of the feeds to these CSTR runs will be determined. The relatively low $\mathrm{H} / \mathrm{C}$ ratio for all $566{ }^{\circ} \mathrm{C}^{+}$products raises a number of issues which will be investigated in Task 4 . The effects of test-condition severity on this value will be investigated. The behavior of these materials on recycle and how these low values affect ultimate conversion to $566{ }^{\circ} \mathrm{C}^{-}$product also will be examined.

\section{Task 4 - Integrated Flow Sheet Testing}

First-Stage Tests, Filtration and Distillation of First-Stage Products

Microautoclave tests were made to examine the effect on coal conversion of lower $\mathrm{KOH}$ catalyst loading and the effect on conversion of reduced solvent to coal ratio. A one-liter autoclave test was made at catalyst loading lower than that used in the Run 23-LA series of tests.

Five microautoclave tests were made to examine the effect on coal conversion of lower $\mathrm{KOH}$ catalyst loading. Tests were made at $375^{\circ} \mathrm{C}$ for $60 \mathrm{~min}$ with solvent/dry coal ratio $=1.8$, and catalyst loadings of $111,83,65,55$, and $45 \mathrm{mmole} / \mathrm{kg}$ dry coal. Coal conversions were $89.9,90.6,90.3,87.9$, and $88.2 \mathrm{wt} \%$, respectively, assuming the $\mathrm{KOH}$ reports to the insolubles. (There is little difference in these conversions even if all the $\mathrm{KOH}$ reports to the solubles, because small amounts of catalyst were used, $0.025-0.010 \mathrm{~g}$.). The results indicate that the first-stage catalyst loading can be reduced from $222 \mathrm{mmole} / \mathrm{kg}$ dry coal used in the one-liter autoclave series (Runs 23x-LA) without reducing coal conversion. The lower usage rate would result in a cost reduction of $\$ 1.00$ to $\$ 1.50$ per barrel of product gasoline. 
Microautoclave tests also were made at reduced solvent/dry coal ratios at $375{ }^{\circ} \mathrm{C}$ for 60 min with $83 \mathrm{mmole} \mathrm{KOH} / \mathrm{kg}$ dry coal. (Table 11). The solvent/dry coal ratios used were 1.5, 1.25, and 1. This is considerably lower than 1.9 which is the ratio used in the one-liter autoclave series 23x-LA. Coal conversions for these tests are all within 2 wt \% (abs.) of 90 wt \%. An additional test (Run 247, Table 11), made at a solvent/dry coal ratio $=1$, but at a reduced $\mathrm{KOH}$ loading (50 mmole/kg dry coal), gave 90 wt \% coal conversion. These encouraging results merit further investigation of reduced catalyst loading and solvent to dry coal ratios.

One-liter autoclave test Run 24-LA was made at the same conditions as the Run 23-LA series, except with half $\mathrm{KOH}$ loading (111 mmole $\mathrm{KOH} / \mathrm{kg}$ dry coal vs. $222 \mathrm{mmole} \mathrm{KOH} / \mathrm{kg}$ dry coal). The test proceeded as planned. A material balance for the run was $100.6 \%$. The recovered products are being analyzed. Mass and elemental balances for Run 24-LA were completed. The coal conversion was $81.7 \mathrm{wt} \%$, considerably lower than conversion (88.8 wt \%) obtained in the corresponding microautoclave test (Run 242) under the same conditions. A repeat of Run 24-LA is planned.

A one-liter autoclave test, Run 25-LA, was made at reduced catalyst loading and reduced solvent to dry coal ratio. The sample was filtered on-line. Products are being analyzed, results will be reported next quarter.

Samples of light distillate oil obtained from the first-stage one-liter autoclave were analyzed by simulated distillation to provide information for the engineering and economic evaluation (Table 12). The distillates of products from the 23-LA series of fist-stage tests were composited and will be used for first-stage solvent recycle tests.

Plans were made to divide the filtrate of Run 23h-LA into three parts and distill each part to an different end point. The three end points will give samples with $25 \%, 50 \%$ and $75 \%$ residue for Task 4 microautoclave tests

\section{Second-Stage Catalytic Upgrading}

Run DARo-2, 300 CSTR, was completed in the continuous hydrotreating system. The Mo loading and temperature were the same as DARo-1, 300 CSTR. ${ }^{1}$ However, the run time was shortened from $60 \mathrm{~min}$ to $30 \mathrm{~min}$ to determine the impact on gas yield and resid conversion. The $566{ }^{\circ} \mathrm{C}^{+}$ resid conversion appears to be high (ca. 67-69\%). The overall material balance for the run will 
be determined upon completion of the duplicate gas analyses, but is expected to be in the mid$90 \%$ range. Elemental analyses and duplicate gas analyses are being obtained.

Dry reactor scrape samples from Runs 23oac-1, 300 CSTR, and 23dfg-1, 300 CSTR, are being analyzed for Mo content. These materials will be used in second-stage recycle tests.

\section{Task 5 - Engineering and Economic Study}

\section{One-Liter Run 23-LA Test Series}

Elemental analysis data for Run 23c-LA were used to prepare an elemental balance for the firststage reactor. However, a large filter cake-rate prorate factor (1.99) was needed to close the poor, as-measured ash balance. This makes the results somewhat suspect. Material and elemental balance data also were obtained for Runs 23d-LA, 23f-LA and 23g-LA. In these tests, the as-measured ash and carbon balances were good. This enabled the calculation of the elemental balances to be made with low prorating factors. The elemental balance also was completed for Run $23 \mathrm{~g}-\mathrm{LA}$, based on analytical data for the filtration products.

In order to complete the elemental balances for all first-stage tests, an adjustment to the measured gas rate was necessary. The adjustment was based on a comparison of the measured excess $\mathrm{CO}_{2}$ yield for each of the runs (through $23 \mathrm{~g}-\mathrm{LA}$ ) vs. the extent of coal deoxygenation as indicated by the liquid and solid product oxygen contents. The excess $\mathrm{CO}_{2}$ yield is the total $\mathrm{CO}_{2}$ yield less the $\mathrm{CO}_{2}$ formed from the $\mathrm{CO}$ shift reaction. The comparison revealed that the excess $\mathrm{CO}_{2}$ yield was much larger than would be possible from the approximately $60 \%$ coal deoxygenation achieved in Runs 23d-LA, 23f-LA, and 23g-LA. A procedure was developed to correct this inconsistency. As a result of the procedure, the measured gas rates were lowered for all the 23-LA series tests. The measured gas composition, which was believed to be accurate, was not changed (Confidential Appendix 2, Tables CA1 to CA3). Based on the above, elemental and material balances were prepared for Runs 23d-LA, 23f-LA, and 23g-LA (Confidential Appendix 2, Tables CA4 to CA6).

Net yields by boiling range cut also were determined for Runs 23d-LA, 23f-LA, and 23g-LA using simulated distillation data (Confidential Appendix 2, Tables CA7 to CA9). 


\section{Second-Stage Catalytic Upgrading}

Data from Runs 23oac-1,300 CSTR, and 23dfg-1,300 CSTR, were compiled. A brief review of these results indicates that there is a significant effect of DMDS and Molyvan L catalyst decomposition on gas yields. Together, the Molyvan $L$ and DMDS are present as $12 \%$ on feed in Run 23-LA series tests. In order to determine the net yields on distilled, filtered first-stage product resid feed, a procedure was developed to estimate yields from the decomposition of the DMDS and Molyvan L contained in the reactor feed (Confidential Appendix 2, Tables CA10 and CA11). Net yields for Runs 23oac-1, 300 CSTR, and 23dfg-1, 300 CSTR, were calculated using these estimates (Confidential Appendix 2, Tables CA12 and CA13). Net yields were determined by boiling range for Runs 23oac-1, 300 CSTR, and 23dfg-1, 300 CSTR, based on simulated distillation data (Confidential Appendix 2, Tables CA14 and CA15).

An elemental balance for Run 263J-1, 300 CSTR, (see above) was completed (Confidential Appendix 2, Table CA16).

\section{Task 6 - Reporting}

All reporting is on schedule. Bi-monthly conference calls were held as scheduled with UK/CAER and LDP. Reports documenting the calls were issued. The technical review meeting for this quarter was canceled to provide participants more time to assemble contributions to the Task 3 Topical Report. A Task 4 Work Plan was drafted and was approved for implementation.

\section{FORECAST AND PLANS}

The Task 3 Topical report will be completed. First-stage tests, designed to decrease process costs by reducing catalyst loading, solvent/dry coal ratio, and system pressure, will be continued under Task 4.

First-stage results from Runs 23d-LA, 23f-LA, and 23g-LA will be compared and evaluated. Second-stage results from Runs 23oac-1, 300 CSTR, and 23dfg-1, 300 CSTR, also will be evaluated. These data will help provide the basis for the Integrated Liquefaction System (ILS) Balance for the Novel Concept Case. Once the ILS balance is completed, work on the support system balances (e.g., upgrading of second-stage product distillates to finished products) will begin. 
Net yields by boiling range will be determined for second-stage Run 263J-1, 300 CSTR, and the product distribution will be compared to the results from Runs 23oac-1, 300 CSTR, and 23dfg-1, 300 CSTR. In addition, the resid conversion rate constants for these runs will be calculated.

It is not possible to determine the exact amount of gas yield from Molyvan $L$. Therefore, it was recommended that in Task 4, an order of magnitude lower loading of Molyvan $L$ or a molybdenum catalyst with much less or no hydrocarbon content should be tested. Tests using lower catalyst loading will be carried out next quarter.

\section{REFERENCES}

1. Brandes, S. D.; Winschel, R. A.; Derbyshire, F. J.; Kimber, G. M.; Anderson, R. K.; Carter, S. D.; Rantell, T.; Vego, A.; Jacques, D.; Peluso, M. "Exploratory Research on Novel Coal Liquefaction Concept, Quarterly Report for April 1 through June 30, 1997", DOE/PC 9505034, August 1997.

2. Brandes, S. D.; Winschel, R. A.; Derbyshire, F. J.; Kimber, G. M.; Anderson, R. K.; Carter, S. D.; Rantell, T.; Vego, A.; Peluso, M. "Exploratory Research on Novel Coal Liquefaction Concept, Task 2 - Evaluation of Process Steps, Topical Report", DOE/PC 95050-22, May 1997. 
TABLE 1

DISTILLATION OF FILTRATES

\begin{tabular}{|c|c|c|c|c|c|c|c|c|c|c|}
\hline \multirow{2}{*}{ Run No. } & \multirow{2}{*}{$\begin{array}{l}\text { Sample } \\
\text { No. }\end{array}$} & \multirow{2}{*}{$\begin{array}{l}\text { Pot } \\
\text { Temp. } \\
\left({ }^{\circ} \mathrm{C}\right)\end{array}$} & \multirow{2}{*}{$\begin{array}{l}\text { Vapor } \\
\text { Temp. } \\
\left({ }^{\circ} \mathrm{C}\right)\end{array}$} & \multirow{2}{*}{$\begin{array}{l}\text { Vapor } \\
\text { Pressure } \\
\text { (torr) }\end{array}$} & \multicolumn{2}{|c|}{$\begin{array}{c}\text { Equivalent Atmospheric } \\
\text { Cut Point }\end{array}$} & \multicolumn{2}{|c|}{ Yields (\%) } & \multirow{2}{*}{$\begin{array}{c}\text { Residue } \\
\text { Softening Point } \\
\left({ }^{\circ} \mathrm{C}\right)\end{array}$} & \multirow{2}{*}{$\begin{array}{c}\text { Mass } \\
\text { Balance } \\
(\%)\end{array}$} \\
\hline & & & & & $\left({ }^{\circ} \mathrm{C}\right)$ & $\left({ }^{\circ} \mathrm{F}\right)$ & Distillate & Residue & & \\
\hline 23aoc-LA & 23aоc-F & 355 & 275 & 5.4 & 454 & 849 & 73.3 & 25.3 & 290 & 98.6 \\
\hline $23 d-L A$ & $23 d-L A$ & 340 & 240 & 5 & 416 & 780 & 78.5 & 29.5 & 165 & 98.1 \\
\hline 23f-LA & 23f-LA & 292 & 243 & 4 & 426 & 799 & 72 & 27.9 & 165 & 99.9 \\
\hline $23 g-L A$ & $23 g-L A$ & 349 & 255 & 4 & 440 & 824 & 74.4 & 25.4 & 255 & 99.9 \\
\hline
\end{tabular}

TABLE 2

SUMMARY OF FILTRATION TESTS

\begin{tabular}{|c|c|c|c|c|c|c|c|c|c|}
\hline $\begin{array}{l}\text { Run } \\
\text { No. }\end{array}$ & $\begin{array}{l}\text { NCF } \\
\text { No. }\end{array}$ & $\begin{array}{c}\text { Filter } \\
\text { Membrane }\end{array}$ & $\begin{array}{c}\text { Aperture, } \\
\text { Retention } \\
(\mu \mathrm{m})\end{array}$ & $\begin{array}{l}\text { Temp } \\
\left({ }^{\circ} \mathrm{C}\right)\end{array}$ & $\begin{array}{l}\text { Viscosity } \\
\text { (MPA s) }\end{array}$ & $\begin{array}{l}\text { Solids in } \\
\text { Feed } \\
(\%)\end{array}$ & $\begin{array}{l}\text { Pressure } \\
\quad(\mathrm{kPa})\end{array}$ & $\begin{array}{c}\text { Cake } \\
\text { Resistivity } \\
\left(\mathrm{m} / \mathrm{kg} \times 10^{10}\right)\end{array}$ & $\begin{array}{l}\text { Total Flow } \\
\text { After } 30 \mathrm{~min} \\
\left(\mathrm{~kg} / \mathrm{m}^{2}\right)\end{array}$ \\
\hline 23- LA & 69 & GFA & 1 & 300 & 0.4 & 5.3 & 210 & 33 & 208 \\
\hline 23a- LA & CONSOL & GFA & 1 & 250 & $\mathrm{n} / \mathrm{m}$ & $\mathrm{n} / \mathrm{m}$ & 210 & $\mathrm{n} / \mathrm{m}$ & $\mathrm{n} / \mathrm{m}$ \\
\hline 23c- LA & CONSOL & GFA & 1 & 250 & $\mathrm{n} / \mathrm{m}$ & $\mathrm{n} / \mathrm{m}$ & 210 & $\mathrm{n} / \mathrm{m}$ & $\mathrm{n} / \mathrm{m}$ \\
\hline $23 d-L A$ & CONSOL & GFA & 1 & 250 & 0.8 & $\mathrm{n} / \mathrm{m}$ & 105 & 8 & 276 \\
\hline 23f- LA & CONSOL & GFA & 1 & 250 & $\mathrm{n} / \mathrm{m}$ & $\mathrm{n} / \mathrm{m}$ & 210 & $\mathrm{n} / \mathrm{m}$ & $\mathrm{n} / \mathrm{m}$ \\
\hline $23 g-L A$ & 71 & GFA & 1 & 250 & 0.8 & 4.6 & 210 & 34 & 225 \\
\hline
\end{tabular}

$\mathrm{n} / \mathrm{m}=$ not measured 
TABLE 3

\section{SECOND-STAGE MICROAUTOCLAVE HYDROTREATING TESTS OF FIRST-STAGE RUN 23D-LA FILTRATE (a)}

\begin{tabular}{|c|c|c|c|c|}
\hline Run No. & $\begin{array}{c}\text { 23d-1, } \\
50 \mathrm{MA} \\
{[R 7-202-1]}\end{array}$ & $\begin{array}{c}\text { 23d-2, } \\
50 \mathrm{MA} \\
{[\mathrm{R} 7-202-2]}\end{array}$ & $\begin{array}{c}\text { 23d-3, } \\
50 \mathrm{MA} \\
{[R 7-210-1]}\end{array}$ & $\begin{array}{l}\text { Average } \pm \\
\text { Standard } \\
\text { Deviation }\end{array}$ \\
\hline Catalyst precursor & Molyvan L & Molyvan L & Molyvan L & - \\
\hline Reaction time, $\min$ & 60 & 60 & 60 & - \\
\hline Reaction Temperature, ${ }^{\circ} \mathrm{C}$ & 440 & 440 & 440 & \\
\hline Mo, ppmw feed & 10,028 & 10,082 & 10,043 & $10,051 \pm 28$ \\
\hline \multicolumn{5}{|c|}{ Products, wt $\%$ feed } \\
\hline $\mathrm{C}_{1}-\mathrm{C}_{3}$ gas $(\mathrm{b})$ & 3.2 & 4.5 & 5.0 & $4.2 \pm 0.9$ \\
\hline $\mathrm{C}_{4}+$ vapor & 1.4 & 2.2 & 2.3 & $1.9 \pm 0.5$ \\
\hline $\mathrm{CO}+\mathrm{CO}_{2}$ & 0.5 & 0.4 & 0.5 & $0.5 \pm 0.1$ \\
\hline $566^{\circ} \mathrm{C}^{-}$ & 51.8 & 51.8 & 53.5 & $52.4 \pm 1.0$ \\
\hline $566^{\circ} \mathrm{C}^{+}$ & 43.1 & 41.1 & 38.7 & $41.0 \pm 2.3$ \\
\hline Total & 100 & 100 & 100 & 100 \\
\hline \multicolumn{5}{|c|}{ Derived values } \\
\hline $\begin{array}{l}\text { Resid conversion, wt \% } 566 \\
{ }^{\circ} \mathrm{C}^{+}\end{array}$ & 42.6 & 45.2 & 48.5 & $45.4 \pm 3.0$ \\
\hline $\begin{array}{l}\mathrm{H}_{2} \text { consumed, mg/ g MAF } \\
\text { feed }\end{array}$ & 46 & 37 & 41 & $41 \pm 4$ \\
\hline $\begin{array}{l}\mathrm{C}_{1}-\mathrm{C}_{3} \text { gas, wt } \% \text { MAF feed } \\
\text { (c) }\end{array}$ & 3.0 & 4.0 & 4.4 & $3.8 \pm 0.7$ \\
\hline $\begin{array}{l}\text { SIMDIS adjustments to } \\
\text { distillation resid weight, } \mathrm{g}\end{array}$ & -0.064 & - & - & - \\
\hline
\end{tabular}

(a) $2 \mathrm{~g}$ samples of $23 \mathrm{~d}-\mathrm{LA}$ distilled filtrate used in each test. The filtrate contained $1.36 \mathrm{wt} \%$ ash.

(b) Calculated from composition, pressure and tempeature of the mounted reactor, using the ideal gas correlation with a compressibility factor of 1.0

(c) Calculated from composition and volume of recovered reactor gas (some gas may be lot transferring the reactor and filling the sample piston) 
TABLE 4

SUMMARY OF $300 \mathrm{~mL}$ CSTR RUNS

\begin{tabular}{|c|c|c|c|c|c|c|c|c|c|c|}
\hline Run No. & Feedstock & $\begin{array}{l}\text { From } \\
\text { Feed } \\
\text { Coal }\end{array}$ & $\begin{array}{l}\text { Digest } \\
\text { solvent }\end{array}$ & $\begin{array}{c}\text { Digest } \\
\text { Temp and } \\
\text { Time }\end{array}$ & Catalyst & $\begin{array}{c}\text { Hydride } \\
\text { Ion } \\
\text { Agent }\end{array}$ & $\begin{array}{l}\text { Feed, } \\
\text { g }\end{array}$ & $\begin{array}{l}\text { Moly- } \\
\text { van } L \text {, } \\
\text { g }\end{array}$ & $\begin{array}{l}\text { DMDS } \\
\text { Feed, } \mathbf{g}\end{array}$ & $\begin{array}{c}\text { Reaction } \\
\text { Temp at } \\
\text { Time }\end{array}$ \\
\hline $\begin{array}{l}\text { 23dfg-1, } 300 \text { CSTR } \\
\text { [R7-223-1] }\end{array}$ & $\begin{array}{l}23 \text { La filtrate } \\
\text { resid blend }\end{array}$ & $\begin{array}{l}\text { Black } \\
\text { Thunder }\end{array}$ & Reilly AO & $\begin{array}{l}375^{\circ} \mathrm{C} \text { for } \\
60 \mathrm{~min}\end{array}$ & $\mathrm{KOH}$ & $E$ & 93 & 11.6 & 7.1 & $\begin{array}{l}440{ }^{\circ} \mathrm{C} \text { for } \\
60 \mathrm{~min}\end{array}$ \\
\hline $\begin{array}{l}\text { 263J-1, } 300 \text { CSTR } \\
\text { [R7-239-1] }\end{array}$ & $\begin{array}{c}\text { Wilsonville } \\
\text { Run 263J } \\
\text { interstage } \\
\text { product }\end{array}$ & $\begin{array}{l}\text { Black } \\
\text { Thunder }\end{array}$ & NA & NA & NA & NA & 100 & 12.3 & 7.4 & $\begin{array}{l}440^{\circ} \mathrm{C} \text { for } \\
60 \mathrm{~min}\end{array}$ \\
\hline
\end{tabular}

NA $=$ Not Available

TABLE 5

HYDROTREATING RESULTS, 300 mL CSTR RUNS

\begin{tabular}{|c|c|c|c|c|c|c|c|c|c|}
\hline Run No. & Feedstock & $\begin{array}{c}566{ }^{\circ} \mathrm{C}^{+} \text {in } \\
\text { Feedstock, } \\
\text { wt } \% \text { MAF } \\
\text { Feed }\end{array}$ & $\begin{array}{c}566{ }^{\circ} \mathrm{C}^{+} \\
\text {Resid } \\
\text { Conv., } \\
\text { wt \% MAF } \\
\text { Feed }\end{array}$ & $\begin{array}{c}\mathrm{C}_{1}-\mathrm{C}_{3} \text { Gas } \\
\text { Yield, } \\
\text { wt } \% \text { MAF } \\
\text { Feed }\end{array}$ & $\begin{array}{c}\mathrm{C}_{1}-\mathrm{C}_{3} \text { Gas } \\
\text { Yield per } \mathrm{g} \\
\text { Resid } \\
\text { Converted }\end{array}$ & $\begin{array}{c}\mathrm{H}_{2} \text { Uptake } \\
\text { by Diff., } \\
\text { mg/g MAF } \\
\text { Feed (a) }\end{array}$ & $\begin{array}{l}\mathrm{H}_{2} \text { Uptake } \\
\text { per g Resid } \\
\text { Converted }\end{array}$ & $\begin{array}{c}\mathrm{H}_{2} \text { Balance, } \\
\text { (Uptake } \\
\text { Basis), \% } \\
\text { (b) }\end{array}$ & $\begin{array}{c}\text { Fixed } \\
\text { Carbon } \\
\text { Ratio, } \\
\text { Out/In(c) }\end{array}$ \\
\hline $\begin{array}{c}\text { 23dfg- } 1,300 \\
\text { CSTR } \\
\text { [R7-223-1] }\end{array}$ & $\begin{array}{l}23 \text { La filtrate } \\
\text { resid blend }\end{array}$ & 80.9 & 65.0 & 15.2 & 28.9 & 33 & 63 & 98 & 0.7 \\
\hline $\begin{array}{c}263 \mathrm{~J}-1,300 \\
\text { CSTR } \\
{[\mathrm{R} 7-239-1]}\end{array}$ & $\begin{array}{c}\text { Wilsonville } \\
\text { Run 263J } \\
\text { interstage } \\
\text { product }\end{array}$ & 66.5 & 43.9 & 18.4 & 63.0 & 27 & 92 & 101 & 1.0 \\
\hline
\end{tabular}

(a) Includes the hydrogen associated with the decomposition of DMDS.

(b) Excludes hydrogen gas calculated to be merely passing through the reactor.

(c) Fixed carbon in product recovered from the reactor (excludes distillate) divided by fixed carbon in the feed. 
TABLE 6

300 mL CSTR TESTS OF FIRST-STAGE FILTRATES (a)

\begin{tabular}{||l|c|c||}
\hline & 230ac-1, 300 CSTR & 23dfg-1, 300 CSTR \\
\hline $566{ }^{\circ} \mathrm{C}^{-}$fraction of feed, wt \% & 6 & 24.6 \\
\hline $566{ }^{\circ} \mathrm{C}^{+}$resid conversion, wt \% & 57 & 65 \\
\hline $\mathrm{H} / \mathrm{C}$ wt ratio of dry resid $566{ }^{\circ} \mathrm{C}$ fraction & 0.039 & 0.042 \\
\hline $\mathrm{C}_{1}-\mathrm{C}_{3}$ gas yield, wt \% MAF feed & 17.3 & 15.2 \\
\hline $\mathrm{H}_{2}$ uptake, $\mathrm{mg} / \mathrm{g} \mathrm{MAF}$ feed & 29 & 33 \\
\hline Fixed carbon recovered in resid, out/in & 0.82 & 0.67 \\
\hline
\end{tabular}

(a) Conditions: $440{ }^{\circ} \mathrm{C}$ for 60 minutes, with $1 \%$ Mo (Molyvan L)

TABLE 7

ELEMENTAL ANALYSES OF DARO-1, 300 CSTR, "REACTOR DRY SCRAPE" PRODUCT

\begin{tabular}{||l|c|c|c|c|c|c|c|c||}
\hline Sample & $\begin{array}{c}\mathrm{C}, \\
\text { wt } \%\end{array}$ & $\begin{array}{c}\mathrm{H}, \\
\text { wt } \%\end{array}$ & $\begin{array}{c}\mathrm{N}, \\
\text { wt } \%\end{array}$ & $\begin{array}{c}\mathrm{S}, \\
\text { wt \% }\end{array}$ & $\begin{array}{c}\mathrm{O}, \\
\text { wt \% } \\
\text { diff. }\end{array}$ & $\begin{array}{c}\text { ash, } \\
\text { wt \% }\end{array}$ & $\begin{array}{c}\text { Total, } \\
\text { wt \% }\end{array}$ & $\begin{array}{c}\mathrm{H} / \mathrm{C} \\
\text { Ratio }\end{array}$ \\
\hline $\begin{array}{l}\text { whole reactor dry } \\
\text { scrape }\end{array}$ & 85.27 & 7.00 & 1.40 & 1.12 & 3.14 & 2.07 & 100.00 & 0.082 \\
\hline $\begin{array}{l}566^{\circ} \mathrm{C}^{-} \text {distillate } \\
\text { fraction }\end{array}$ & 91.53 & 7.15 & 1.01 & 0.03 & 0.11 & 0.17 & 100.00 & 0.078 \\
\hline $\begin{array}{l}566^{\circ} \mathrm{C}^{-} \text {distillate } \\
\text { fraction, normalized } \\
\text { to } 100 \% \text { recovery }\end{array}$ & 82.51 & 8.81 & 1.57 & 0.43 & 6.65 & 0.03 & 100.00 & 0.107 \\
\hline $\begin{array}{l}566^{\circ} \mathrm{C}^{+} \text {residual } \\
\text { fraction }\end{array}$ & 89.44 & 4.27 & 1.14 & 2.16 & -2.17 & 5.16 & 100.00 & 0.048 \\
\hline
\end{tabular}


TABLE 8

ELEMENTAL ANALYSES OF 23oac-1, 300 CSTR, "REACTOR DRY SCRAPE" PRODUCT

\begin{tabular}{||l|c|c|c|c|c|c|c|c||}
\hline \multicolumn{1}{|c|}{ Sample } & $\begin{array}{c}\mathbf{C}, \\
\mathbf{w t} \%\end{array}$ & $\begin{array}{c}\mathbf{H}, \\
\mathbf{w t} \%\end{array}$ & $\begin{array}{c}\mathbf{N}, \\
\mathbf{w t} \%\end{array}$ & $\begin{array}{c}\mathbf{S}, \\
\mathbf{w t} \%\end{array}$ & $\begin{array}{c}\mathbf{O}, \mathbf{w} \\
\mathbf{\text { diff }}\end{array}$ & $\begin{array}{c}\text { Ash, } \\
\mathbf{w t} \%\end{array}$ & $\begin{array}{c}\text { Total, } \\
\text { wt \% }\end{array}$ & $\begin{array}{c}\mathbf{H} / \mathbf{C} \\
\text { Ratio }\end{array}$ \\
\hline whole reactor dry scrape & 84.52 & 6.27 & 1.51 & 1.15 & 0.03 & 6.52 & 100.00 & 0.074 \\
\hline $566^{\circ} \mathrm{C}^{-}$distillate fraction & 82.96 & 8.34 & 1.46 & 0.04 & 7.20 & 0.00 & 100.00 & 0.101 \\
\hline $\begin{array}{l}566^{\circ} \mathrm{C}^{-} \text {distillate fraction, } \\
\text { normalized } \\
\text { to } 100 \% \text { recovery }\end{array}$ & 88.07 & 10.44 & 1.67 & 0.29 & 2.56 & -3.03 & 100.00 & 0.119 \\
\hline $566^{\circ} \mathrm{C}^{+}$residual fraction & 81.91 & 3.20 & 1.39 & 1.78 & $(1.83)$ & 13.55 & 100.00 & 0.039 \\
\hline \hline
\end{tabular}

TABLE 9

ELEMENTAL ANALYSES OF 23dfg-1, 300 CSTR, "REACTOR DRY SCRAPE" PRODUCT

\begin{tabular}{||l|c|c|c|c|c|c|c|c||}
\hline \multicolumn{1}{|c|}{ Sample } & $\begin{array}{c}\mathbf{C}, \\
\mathbf{w t} \%\end{array}$ & $\begin{array}{c}\mathbf{H}, \\
\mathbf{w t} \%\end{array}$ & $\begin{array}{c}\mathbf{N}, \\
\mathbf{w t} \%\end{array}$ & $\begin{array}{c}\mathbf{S}, \\
\mathbf{w t} \%\end{array}$ & $\begin{array}{c}\mathbf{0}, \mathbf{w t} \% \\
\text { diff }\end{array}$ & $\begin{array}{c}\text { Ash, } \\
\mathbf{w t} \%\end{array}$ & $\begin{array}{c}\text { Total, } \\
\mathbf{w t} \%\end{array}$ & $\begin{array}{c}\mathbf{H} / \mathbf{C} \\
\text { Ratio }\end{array}$ \\
\hline whole reactor dry scrape & 82.18 & 6.84 & 1.665 & 1.075 & 2.52 & 5.72 & 100.00 & 0.083 \\
\hline $566^{\circ} \mathrm{C}$ - distillate fraction & 88.98 & 7.08 & 1.35 & 0.04 & 2.51 & 0.04 & 100.00 & 0.080 \\
\hline $\begin{array}{l}566^{\circ} \mathrm{C} \text { - distillate fraction, } \\
\text { normalized to } 100 \% \\
\text { recovery }\end{array}$ & 83.08 & 9.73 & 2.03 & 0.12 & 7.24 & -2.19 & 100.00 & 0.117 \\
\hline $566^{\circ} \mathrm{C}$ + residual fraction & 81.11 & 3.44 & 1.24 & 2.20 & -3.02 & 15.03 & 100.00 & 0.042 \\
\hline
\end{tabular}


TABLE 10

ELEMENTAL ANALYSES OF 263J-1, 300 CSTR, "REACTOR DRY SCRAPE" PRODUCT

\begin{tabular}{||l|c|c|c|c|c|c|c|c||}
\hline \multicolumn{1}{|c|}{ Sample } & $\begin{array}{c}\mathbf{C}, \\
\mathbf{w t} \%\end{array}$ & $\begin{array}{c}\mathbf{H}, \\
\mathbf{w t} \%\end{array}$ & $\begin{array}{c}\mathbf{N}, \\
\mathbf{w t} \%\end{array}$ & $\begin{array}{c}\mathbf{S}, \\
\mathbf{w t} \%\end{array}$ & $\begin{array}{c}\mathbf{0}, \mathbf{w t} \% \\
\mathbf{d i f f}\end{array}$ & $\begin{array}{c}\text { Ash, } \\
\mathbf{w t} \%\end{array}$ & $\begin{array}{c}\text { Total, } \\
\mathbf{w t} \%\end{array}$ & $\begin{array}{c}\mathbf{H} / \mathbf{C} \\
\text { Ratio }\end{array}$ \\
\hline $\begin{array}{l}\text { whole reactor dry } \\
\text { scrape }\end{array}$ & 68.47 & 4.56 & 0.60 & 2.72 & 0.36 & 23.30 & 100.00 & 0.067 \\
\hline $\begin{array}{l}566^{\circ} \mathrm{C}-\text { distillate } \\
\text { fraction }\end{array}$ & 86.10 & 8.28 & 1.03 & 0.03 & 4.56 & 0.00 & 100.00 & 0.096 \\
\hline $\begin{array}{l}566^{\circ} \mathrm{C} \text { - distillate } \\
\text { fraction, normalized } \\
\text { to } 100 \% \text { recovery }\end{array}$ & 91.78 & 10.91 & -0.02 & 1.52 & 0.17 & -4.36 & 100.00 & 0.119 \\
\hline $\begin{array}{l}566^{\circ} \mathrm{C}+\text { residual } \\
\text { fraction }\end{array}$ & 59.76 & 2.19 & 0.83 & 3.16 & 0.43 & 33.63 & 100.00 & 0.037 \\
\hline
\end{tabular}

TABLE 11

FIRST-STAGE MICROAUTOCLAVE TESTS AT REDUCED SOLVENT/COAL RATIOS

Black Thunder Mine Coal

$375^{\circ} \mathrm{C}, 60 \mathrm{~min}$

\begin{tabular}{||l|c|c|c||}
\hline \hline Run No. & $\begin{array}{c}\text { Solvent (a) } \\
\text { /dry coal }\end{array}$ & $\begin{array}{c}\text { Catalyst (b), } \\
\text { mmole/kg dry coal }\end{array}$ & $\begin{array}{c}\text { Coal Conversion, } \\
\text { wt\% }\end{array}$ \\
\hline 242 & 1.5 & 83 & 88.8 \\
\hline 245 & 1.25 & 83 & 92.1 \\
\hline 246 & 1.0 & 83 & 88.4 \\
\hline 247 & 1.0 & 50 & 89.4 \\
\hline
\end{tabular}

(a) solvent: Reilly Industries anthracene oil

(b) catalyst: $\mathrm{KOH}$ 
TABLE 12

SIMULATED DISTILLATION OF FIRST-STAGE LIGHT DISTILLATE OIL

\begin{tabular}{|c|c|c|c|c|c|c|}
\hline \multicolumn{2}{|c|}{ Sample No. } & 23c-LA & 23d-LA & 23f-LA & $23 g-L A$ & 23h-LA \\
\hline \multicolumn{2}{|c|}{ Found Recovery (\%) } & 87.5 & 91.7 & 96.8 & 98.5 & 97.5 \\
\hline b pt $\left({ }^{\circ} \mathrm{C}\right)$ & b pt $\left({ }^{\circ} \mathrm{F}\right)$ & \multicolumn{5}{|c|}{ amount in fraction (\%) } \\
\hline$<150$ & $<302$ & 3.8 & 2.5 & 2.6 & 2.7 & 2.6 \\
\hline $150-200$ & $302-392$ & 8.0 & 8.5 & 9.1 & 9.0 & 8.8 \\
\hline $200-250$ & $392-482$ & 30.9 & 33.3 & 32.1 & 32.9 & 31.7 \\
\hline $250-300$ & $482-572$ & 10.9 & 11.9 & 14.2 & 14.4 & 13.5 \\
\hline $300-350$ & $572-662$ & 20.4 & 20.7 & 21.8 & 22.0 & 22.6 \\
\hline $350-400$ & $662-752$ & 10.5 & 11.7 & 12.4 & 12.9 & 12.9 \\
\hline $400-450$ & $752-842$ & 2.4 & 2.7 & 3.2 & 3.0 & 3.5 \\
\hline $450-500$ & $842-932$ & 0.6 & 0.4 & 0.9 & 1.2 & 1.0 \\
\hline $500-550$ & $932-1022$ & 0.0 & 0.0 & 0.5 & 0.4 & 0.9 \\
\hline $550-600$ & $1022-1112$ & 0.0 & 0.0 & 0.0 & 0.0 & 0.0 \\
\hline
\end{tabular}

\begin{tabular}{|c|c|c|c|c|c|c|}
\hline bpt $\left({ }^{\circ} \mathrm{C}\right)$ & bpt $\left({ }^{\circ} \mathrm{F}\right)$ & \multicolumn{5}{|c|}{ amount bpt $<\mathrm{T}^{\circ}(\%)$} \\
\hline$<150$ & $<302$ & 3.8 & 2.5 & 2.6 & 2.7 & 2.6 \\
\hline$<200$ & $<392$ & 11.8 & 11.0 & 11.7 & 11.7 & 11.4 \\
\hline$<250$ & $<482$ & 42.7 & 44.3 & 43.8 & 44.6 & 43.1 \\
\hline$<300$ & $<572$ & 53.6 & 56.2 & 58.0 & 59.0 & 56.6 \\
\hline$<350$ & $<662$ & 74.0 & 76.9 & 79.8 & 81.0 & 79.2 \\
\hline$<400$ & $<752$ & 84.5 & 88.6 & 92.2 & 93.9 & 92.1 \\
\hline$<450$ & $<842$ & 86.9 & 91.3 & 95.4 & 96.9 & 95.6 \\
\hline$<500$ & $<932$ & 87.5 & 91.7 & 96.3 & 98.1 & 96.6 \\
\hline$<550$ & $<1022$ & 87.5 & 91.7 & 96.8 & 98.5 & 97.5 \\
\hline$<600$ & $<1112$ & 87.5 & 91.7 & 96.8 & 98.5 & 97.5 \\
\hline
\end{tabular}

